\title{
Menakar Kurikulum Geografi 2013 dalam Pengembangan Nilai Patriotisme
}

\author{
AHMAD YANI \\ Fakultas Pendidikan Ilmu Pengetahuan Sosial, Universitas Pendidikan Indonesia, Jl. Dr. Setiabudi 229 Bandung \\ email: ahmadyani@upi.edu
}

\begin{abstract}
This study has the objective to measure the Geography Curriculum in 2013 Curriculum (K-13) in the development of the value of patriotism. The method employed is the analysis of documents related to the geography curriculum. There are four findings in this research, they are (1) based on documents from the Pusat Kurikulum dan Buku (Centre for Curriculum and Books), curriculum Geography has a goal to build character and cultivate patriotism as to be pride as an Indonesian; (2) compared with the previous curriculum, geography subjects in the $\mathrm{K}-13$ greatly accentuate the materials of Indonesian geography; (3) Content of the patriotism value has Sumpah Pemuda's spirit (Indonesian Youths' Vow for Indonesian Independence) as its background; and (4) to develop the value of patriotism, Geography learning uses a direct approach (instructional effects) and indirect approach (nurturant effects) to develop the value of patriotism. In direct approach, values of patriotism are delivered through advice by creating a learning environment that enables the emergence of opportunities for teachers to give advices. In inndirec approach, the values of patriotism are developed through methods of recitation and media that have a positive impact on the development of patriotism.
\end{abstract}

Keywords: geography, Indonesia, curriculum, nurturat effect, patriotism

\begin{abstract}
Abstrak. Penelitian ini memiliki tujuan untuk menakar Kurikulum Geografi pada Kurikulum 2013 (K-13) dalam pengembangan nilai patriotisme. Metode penelitian yang digunakan adalah analisis dokumen yang terkait dengan kurikulum geografi. Ada empat hasil penelitian yang ditemukan yaitu (1) berdasarkan dokumen dari Pusat Kurikulum dan Perbukuan, Kurikulum Geografi memiliki tujuan untuk membina karakter cinta tanah air dan memupuk kebanggaan sebagai bangsa Indonesia; (2) mata pelajaran geografi pada K-13 sangat menonjolkan materi Geografi Indonesia dibandingkan dengan kurikulum sebelumnya; (3) Muatan nilai patriotismenya dilatar-belakangi oleh semangat nilai-nilai sumpah pemuda; dan (4) untuk mengembangkan nilai patriotisme, pembelajaran Geografi menggunakan pendekatan langsung (instructional effects) dan tidak langsung (nurturant effects). Pada pembelajaran langsung, disampaikan melalui nasihat dan menciptakan suasana pembelajaran yang memungkinkan munculnya kesempatan bagi guru memberi teguran dan penguatan dan pada pembelajaran secara tidak langsung, nilai patriotisme dikembangkan melalui metode penugasan dan penggunaan media pembelajaran yang memiliki dampak positif terhadap pengembangan patriotisme.
\end{abstract}

Kata kunci: geografi, indonesia, kurikulum, nurturat effect, patriotisme

\section{Pendahuluan}

Akhir-akhir ini, masyarakat Indonesia merasa khawatir terhadap gejala menurunnya semangat patriotisme (cinta tanah air) di kalangan generasi muda. Gejala tersebut dapat diamati dari memudarnya kebanggaan sebagai bangsa Indonesia. Mereka lebih mencintai produk luar negeri daripada produk dalam negeri, tidak banyak mengetahui tentang kondisi dan potensi wilayah negaranya, kurang peduli terhadap penguasaan pihak asing terhadap berbagai sumber daya alam nasional, dan tidak peduli terhadap kerusakan lingkungan yang ditimbulkan oleh eksploitasi sumber daya lingkungan yang berlebihan.

Memudarnya semangat patriotisme akan mengancam keutuhan negara. Jika rakyat Indonesia dibiarkan lebih mencintai produk

Received: 20 Juni 2015, Revision: 14 September 2015, Accepted: 21 Desember 2015

Print ISSN: 0215-8175; Online ISSN: 2303-2499. Copyright@2015. Published by Pusat Penerbitan Universitas (P2U) LPPM Unisba Terakreditasi SK Kemendikbud, No.040/P/2014, berlaku 18-02-2014 s.d 18-02-2019 
luar negeri daripada produk dalam negeri, maka secara perlahan akan mendorong setiap orang mengikuti gaya hidup, selera, dan trend budaya asing dalam memenuhi kebutuhan hidupnya. Dalam konteks ekonomi, perilaku tersebut akan menghambat pertumbuhan ekonomi nasional dan mempercepat krisis ekonomi.

Dampak lanjutan dari krisis ekonomi tentu saja akan menyuburkan sikap individulisme, persaingan, dan konflik horizontal, dan pada puncaknya akan mengancam keutuhan bangsa dan Negara Kesatuan Republik Indonesia (NKRI). Oleh karena itu, institusi pendidikan baik formal maupun non-formal harus mampu membangkitkan kembali semangat patriotisme.

Selain alasan yang telah digambarkan di atas, pengembangan semangat patriotisme semakin mendesak karena Indonesia telah memasuki era Masyarakat Ekonomi ASEAN (MEA). Era MEA menjadi peluang bagi bangsa Indonesia karena bertambahnya peluang lapangan pekerjaan lintas negara. Sebaliknya, dapat menjadi ancaman bagi bangsa Indonesia, karena tidak dapat menolak masuknya barang-barang dari negara-negara ASEAN yang secara langsung akan mengancam keberadaan perusahaan nasional.

Beberapa tahun ke depan, kita pun akan mendapati "bonus demografi," yaitu struktur kependudukan dengan proporsi jumlah penduduk usia produktif (15 tahun - 64 tahun) lebih besar daripada penduduk usia nonproduktif. Bonus demografi sebagai investasi sumber daya manusia adalah peluang untuk meningkatkan kesejahteraan namun pada sisi yang lain akan menjadi beban sosial jika penduduk usia produktif tidak berkualitas. Penduduk usia produktif akan membutuhkan berbagai sumber pangan, energi, dan barang kebutuhan lainnya dalam jumlah yang sangat besar. Jika pola hidup generasi muda tidak dilandasi oleh semangat patriotisme, maka bisa jadi mereka akan "menjual" negara untuk kepentingan pribadinya semata yang pada gilirannya kembali akan mengancam keutuhan NKRI.

Dengan memahami situasi yang sedang dan akan dihadapi di masa depan, pemerintah Indonesia melalui Kementerian Pendidikan dan Kebudayaan (Kemendikbud) menggagas dan memperbaiki kurikulum pendidikan di tanah air yang dikenal dengan nama Kurikulum 2013 (K-13). Sebuah kurikulum yang dirancang dengan misi yang luhur yaitu ingin menumbuhkembangkan sikap, pengetahuan, dan keterampilan peserta didik yang siap menghadapi era pasar bebas di masa depan. Dari sekian banyak mata pelajaran yang diajarkan di Sekolah Menengah Atas (SMA), geografi adalah mata pelajaran yang dapat "dimanfaatkan" untuk memerkenalkan kondisi wilayah negara Indonesia. Selain itu, geografi adalah mata pelajaran yang paling relevan untuk membahas potensi dan kekayaan barang tambang nasional, kondisi penduduk, kekayaan flora dan fauna, kesuburan tanah, penggalian potensi energi baru dan terbarukan, keragaman budaya bangsa, dan pengembangan wilayah. Melalui mata pelajaran geografi, guru dapat mengajak peserta didik untuk mencintai negaranya, menyiapkan diri untuk mampu bersaing, dan tentu saja membangun harga dirinya sebagai bangsa yang besar.

Namun, apakah materi geografi pada $\mathrm{K}-13$ telah memuat materi sebagaimana yang telah disebutkan? Penelitian ini memiliki tujuan untuk menganalisis dan menakar Kurikulum Geografi pada K-13 dalam aspek konten atau isi nilai patriotisme. Metode yang digunakan adalah analisis dokumen yang terkait dengan kurikulum geografi, baik Kurikulum tahun 2013 maupun kurikulum sebelumnya. Untuk mencapai tujuan tersebut, tulisan ini akan dibagi menjadi beberapa subbab yaitu (1) Karakteristik mata pelajaran Geografi; (2) Muatan materi tentang keindonesiaan dalam Kurikulum Geografi 2013; (3) muatan nilai Pendidikan Karakter pada Kurikulum Geografi 2013; dan (4) Pembelajaran Geografi dalam menumbuhkan nilai patriotisme.

\section{Karakteristik Mata Pelajaran Geografi}

Geografi adalah ilmu yang menelaah bumi dalam hubungannya dengan manusia (Daldjoeni, 2014; 1). Fokus kajian geografi sejak dulu tidak terlepas dari permukaan bumi dan kehidupan manusia yang berada di atasnya. Sejak zaman Eratosthenes (276194 SM), geografi masih didefinisikan sebagai ilmu yang menggambarkan permukaan bumi (writing about the earth).

Enok Maryani (2015: 33 ) menggambarkan pengertian geografi sejak zaman Ptolomy (150 SM) yaitu bahwa,

Geografi merupakan ilmu yang menyediakan pandangan dan informasi mengenai lokasi tempat-tempat di permukaan bumi melalui peta. Dari pengertian yang sederhana tersebut, Von Humboldt (1845) mensintesiskan antara objek kajian geografi yang bersifat umum (general) menjadi yang bersifat khusus (specialization) melalui penguku- 
ran, pemetaan, dan regionalisasi. William Hughes (1863) mengembangkan lebih jauh, ia memandang bahwa geografi tidak sekadar mendeksripsikan tempat-tempat di permukaan bumi, tetapi juga bertujuan untuk mencari, menemukan, mengklasifikasikan, membandingkan, dan melakukan generalisasi.

Memasuki abad ke-21, CCGE (Canadian Council for Geographic Education) mendefinisikan geografi sebagai ilmu yang berusaha mengorganisasikan permukaan bumi, proses interaksi antara elemen fisik dengan elemen manusia, menggambarkan tempat atau ruang muka bumi, dan mengarahkan proses interaksi antar-tempat untuk terciptanya kehidupan yang lebih baik, efektif dan efisien.

Selanjutnya, secara pragmatis, geografi didefinisikan sebagai sebuah ilmu yang menafsirkan realitas perbedaan wilayah di permukaan bumi seperti apa adanya, tidak hanya dalam arti perbedaan-perbedaan yang bersifat spesifik, tetapi juga dalam arti keseluruhan fenomena di setiap tempat yang berbeda keadaannya dengan di tempat lain (Suharyono dan Moch. Amien, 2013: 19).

Pusat Kurikulum dan Perbukuan (2013: 1) dalam bukunya tentang Kompetensi Dasar Geografi, mendefinsikan geografi sebagai:

ilmu yang mempelajari hubungan kausal
berbagai gejala dan peristiwa yang terjadi
di muka bumi, baik fisik maupun yang me-
nyangkut makhluk hidup beserta permasa-
lahannya melalui pendekatan keruangan,
ekologi, dan regional. Hasil kajian geogra-
fi diarahkan untuk kepentingan program,
proses, dan keberhasilan pembangunan.

Dalam mendeskripsikan, memahami, mengidentifikasi, mengevaluasi, dan mengatasi masalah pembangunan, geografi dibantu oleh sejumlah teknologi seperti peta, penginderaan jauh, dan Sistem Informasi Geografis (SIG). Dari pengertian yang terakhir terlihat adanya fungsi edukasi mata pelajaran geografi yaitu mendidik peserta didik untuk mampu mengatasi permasalahan pembangunan dan mencintai negaranya.

Dari sejumlah definisi di atas, karakteristik dari mata peajaran geografi terlihat dari rumusan tujuannya. Dalam dokumen yang dikeluarkan oleh Puskurbuk (2013: 1) mata pelajaran Geografi memiliki tujuan untuk (1) memahami pola spasial, lingkungan dan kewilayahan, serta proses yang berkaitan dengan gejala geosfera dalam konteks nasional dan global; (2) menguasai keterampilan dasar dalam memperoleh data dan informasi, menerapkan pengetahuan geografi dalam kehidupan sehari-hari, dan mengomunikasikannya untuk kepentingan kemajuan bangsa Indonesia; (3) menampilkan perilaku peduli terhadap lingkungan hidup dan memanfaatkan sumber daya alam secara arif serta memiliki toleransi terhadap keragaman budaya bangsa; (4) menampilkan perilaku cinta tanah air, bangga sebagai bangsa Indonesia, dan bertanggung jawab terhadap keutuhan Negara Kesatuan Republik Indonesia yang berlandaskan pada Pancasila dan UUD 1945. Dari rumusan tujuan tersebut, khususnya pada point ke-empat terlihat bahwa geografi sangat mengharapkan agar peserta didik memiliki perilaku cinta tanah air, bangga sebagai bangsa Indonesia, dan bertanggung jawab terhadap keutuhan Negara Kesatuan Republik Indonesia yang berlandaskan pada Pancasila dan UUD 1945.

Apakah benar mata pelajaran geografi dapat dimanfaatkan sebagai mata pelajaran yang mengembangkan nilai-nilai patriotisme? Jawabannya ada pada pendapat Gunardo, R.B (2014: 1) yang menjelaskan bahwa

Ilmu geografi (khususnya pada cabang geogra-
fi politik) adalah ilmu yang dapat dijadikan
alat pembentuk karakter bangsa. Geografi
dapat memberi kesadaran bagaimana kondisi
sumber daya alam dan sumber daya manu-
sia merupakan modal membangun bangsa
agar menjadi bangsa yang maju dan besar.

Pernyataan Gunardo R.B tentu saja ada benarnya karena jika diperhatikan secara saksama, dalam kehidupan berbangsa dan bernegara, terkadang banyak sekali yang tidak selaras. Ilmu geografi akan mempertanyakan mengapa kehidupan manusia di suatu wilayah negara tidak sejahtera padahal kekayaan alamnya melimpah. Di tempat lain terkadang sebaliknya, sumber daya alam sangat minim tetapi kehidupan penduduknya sangat sejahtera.

Dalam kasus Indonesia, kita mengetahui bahwa luas lahan pertanian Indonesia sangat luas (data tahun 2015, Indonesia memiliki seluas lahan pertanian mencapai 700 ribu hektar). Dengan lahan pertanian yang sangat luas, Indonesia memiliki potensi untuk mampu berswasembada pangan. Namun pada kenyataannya, masih mengimpor beras dari negara lain.

Bukan hanya beras, komiditas bahan pangan yang seharusnya dapat terpenuhi dari dalam negeri ternyata masih diimpor dari negara lain seperti gula pasir, daging, susu, bahkan garam dapur. Menurut data dari Badan Informasi Geospasial (BIG) total panjang garis pantai Indonesia adalah 99.093 kilometer, sangat berpotensi sebagai negara 
penghasil garam namun pada kenyataannya setiap tahun Indomesia meng-impor garam dapur. Berdasarkan data BPS, total garam yang diimpor selama Januari 2014 mencapai 278 ribu ton, atau naik $78 \%$ secara volume. Sedangkan nilai impornya mencapai US\$ 13,4 juta, atau naik $75 \%$ secara nilai impor (Jefriando. M. 2014)

Permasalahan ini bukan hanya disebabkan oleh faktor tata niaga bahan pangan yang masih lemah tetapi juga faktor kesadaran yang rendah dari bangsa Indonesia secara keseluruhan. Pemerintah dengan segala kewenangannya dapat menunjukkan komitmennya untuk memberi lapangan pekerjaan yang sangat luas bagi warga negara di tanah air.

Angkatan kerja Indonesia yang pergi menjadi Tenaga Kerja Indonesia (TKI) bukan tidak mencintai terhadap tanah airnya, tetapi sebagian dari mereka terpaksa menjadi TKI untuk menghidupi keluarganya. Masalah ini dapat difahami jika peserta didik belajar geografi. Sumber masalah yang utama diawali dari rendahnya pengetahuan dan wawasan masyarakat Indonesia terhadap keadaan, kondisi, dan potensi wilayah negaranya sendiri dan informasi tentang wilayah dan potensi Indonesia dianggap sangat minim.

\section{Muatan Materi Keindonesiaan dalam Kurikulum Geografi 2013}

Materi keindonesiaan dalam Kurikulum 2013 cukup menonjol dibandingkan dengan kurikulum sebelumnya. Berdasarkan hasil telaah dokumen, mata pelajaran geografi pada Kurikulum 2004 tidak banyak memperkenalkan tentang kondisi wilayah NKRI. Materi yang dikaji hanya bersifat umum dan hanya berorientasi pada disiplin ilmu. Berbeda dengan Kurikulum 2013, mata pelajaran geografi terlihat disengaja ingin memperkenalkan wilayah dan potensi Indonesia (lihat kembali rumusan tujuan mata pelajaran geografi pada Kurikulum 2013 di bagian awal tulisan ini). Berikut ini perbandingan materi pokok yang diajarkan pada Kurikulum 2004 dan Kurikulum 2013 yang patut dicermati untuk kepentingan analisis kurikulum.

Berdasarkan uraian di atas, terlihat bahwa Kurikulum Geografi tahun 2013 lebih banyak mengkaji tentang wilayah Indonesia. Pada kelas $X$, materinya bersifat umum sedangkan pada kelas XI dan XI secara ekplisit membahas tentang wilayah Indonesia. Dengan muatan materi Geografi 2013, maka dapat dipastikan bahwa kelak peserta didik akan lebih mengenal wilayah NKRI secara lebih baik. Mereka akan mengenal aspek letak, bentuk, dan luas wilayah negaranya sebagai poros maritim dunia; juga akan mengetahui potensi wilayah seperti sumber daya alam untuk memeroleh bahan pangan, bahan dasar untuk industri, maupun untuk penyediaan energi baru dan terbarukan. Di kelas XII, sebagian dari materinya ada juga yang diarahkan untuk mengkaji tentang wilayah regional negara-negara tetangga yang dimaksudkan untuk menjalin hubungan kerjasama antar negara maupun dalam menyiapkan diri dalam pasar bebas global. Dengan konten Kurikulum Geografi yang sarat dengan upaya memperkenalkan wilayah dan potensi Indonesia, maka geografi berpotensi untuk membangun nilai-nilai patriotisme peserta didik.

\section{Muatan Nilai Patriotisme pada Kurikulum Geografi 2013}

Secara umum, aliran filsafat yang mendasari Kurikulum 2013 tidak jauh berbeda dengan kurikulum 2004 dan kurikulum 2006 (KTSP), yaitu keduanya dikembangkan dari Kurikulum Berbasis Kompetensi (KBK). Kurikulum yang berbasis kompetensi dikembangkan untuk meningkatkan kemampuan dan atau penguasaan kompetensi dalam bidang-bidang praktis di lapangan pekerjaan (Ahmad Yani, 2014: 40).

Kedua kurikulum tersebut dilatarbelakangi oleh harapan yang besar terhadap peningkatan kemampuan bangsa Indonesia dalam menghadapi persaingan pasar bebas dengan negara-negara lain. Perbedaannya sangat signifikan, pada Kurikulum 2006 pendidikan karakter hanya sebagai suplemen yang disisipkan pada Kurikulum Tingkat Satuan Pendidikan (KTSP) sedangkan pada Kurikulum 2013, pendidikan karakter sudah terintegrasikan dalam setiap Kompetensi Inti (KI) dan Kompetensi Dasar (KD) mata pelajaran. Nilai-nilai pendidikan karakter secara eksplisit dinyatakan dalam rumusan KI- 1 (sikap spiritual) dan KI-2 (sikap sosial).

Peraturan Menteri Pendidikan dan Kebudayaan Nomor 64 Tahun 2013 tentang Standar Isi Pendidikan Dasar dan Menengah, merumuskan bahwa kompetensi yang diharapkan muncul (khusunya pada KI-2) adalah agar peserta didik dapat menghayati dan mengamalkan perilaku jujur, disiplin, tanggung jawab, peduli (gotong royong, 
Tabel 1

Materi Pokok Geografi dan Muatan Keindonesiaan pada Kurikulum 2013

\begin{tabular}{|c|c|c|}
\hline Materi Pokok & $\begin{array}{c}\text { Kurikulum } \\
2004(2006)\end{array}$ & Kurikulum 2013 \\
\hline 1. Pengetahuan hakikat ilmu geografi. & $\sqrt{ }$ & $\sqrt{ }$ \\
\hline 2. Sejarah pembentukan muka bumi (planet bumi) & $\sqrt{ }$ & $\sqrt{ }$ \\
\hline 3. Dinamika perubahan atmosfer & $\sqrt{ }$ & $\sqrt{ }$ \\
\hline 4. dinamika perubahan litosfer & $\sqrt{ }$ & $\sqrt{ }$ \\
\hline 5. dinamika perubahan hidrosfer & $\sqrt{ }$ & $\sqrt{ }$ \\
\hline 6. dinamika perubahan pedosfer & $\sqrt{ }$ & - \\
\hline 7. Morfologi pesisir dan laut serta ciri-cirinya. & $\sqrt{ }$ & - \\
\hline $\begin{array}{l}\text { 8. Kualitas lingkungan hidup dan pembangunan } \\
\text { berwawasan lingkungan. }\end{array}$ & $\sqrt{ }$ & $\sqrt{ }$ \\
\hline 9. Dinamika perubahan biosfer & $\sqrt{ }$ & $\sqrt{ }$ \\
\hline 10.Dinamika perubahan antroposfer & $\sqrt{ }$ & $\begin{array}{l}\text { Mengkaji penduduk } \\
\text { Indonesia }\end{array}$ \\
\hline $\begin{array}{l}\text { 11.Informasi tentang persebaran, pola, dan hubungan } \\
\text { antar obyek geografi melalui peta dan citra penginderaan } \\
\text { jauh. }\end{array}$ & Bersifat umum & $\begin{array}{l}\text { Difokuskan pada kajian } \\
\text { tata guna lahan dan } \\
\text { transportasi. }\end{array}$ \\
\hline 12.Persebaran lokasi sumber daya alam & Bersifat umum & $\begin{array}{l}\text { Mengkaji SDA } \\
\text { Indonesia }\end{array}$ \\
\hline 13.Kemampuan menerapkan konsep dasar perwilayahan. & Bersifat umum & $\begin{array}{l}\text { Mengkaji SDA } \\
\text { Indonesia }\end{array}$ \\
\hline 14.Sistem Informasi Geografis. & Bersifat umum & $\begin{array}{l}\text { Mengambil kasus di } \\
\text { Indonesia }\end{array}$ \\
\hline 15.Pola keruangan desa dan kota & Bersifat umum & $\begin{array}{l}\text { Diarahkan untuk } \\
\text { untuk pengembangan } \\
\text { ekonomi daerah. }\end{array}$ \\
\hline $\begin{array}{l}\text { 16.Pengembangan wilayah di negara maju dan negara } \\
\text { berkembang. }\end{array}$ & $\sqrt{ }$ & $\begin{array}{c}\text { Dalam perencanaan } \\
\text { pembangunan nasional }\end{array}$ \\
\hline 17.Langkah-langkah penelitian geografi & - & $\sqrt{ }$ \\
\hline 18. Mitigasi dan adaptasi bencana alam & - & $\sqrt{ }$ \\
\hline 19.Sebaran barang tambang di Indonesia. & - & $\sqrt{ }$ \\
\hline $\begin{array}{l}\text { 20.Ketahanan pangan nasional, penyediaan bahan } \\
\text { industri, dan energi alternatif. }\end{array}$ & - & $\sqrt{ }$ \\
\hline 21. Keragaman budaya bangsa. & - & $\sqrt{ }$ \\
\hline
\end{tabular}

kerjasama, toleran, damai), santun, responsif dan pro-aktif dan menunjukkan sikap sebagai bagian dari solusi atas berbagai permasalahan dalam berinteraksi secara efektif dengan lingkungan sosial dan alam serta dalam menempatkan diri sebagai cerminan bangsa dalam pergaulan dunia. "Kompetensi" sikap tersebut tidak diajarkan tetapi dikembangkan selama proses pembelajaran melalui pembelajaran yang memiliki dampak ikutan (nurturant effect) terhadap pengembangan sikap.

Permasalahan yang kemudian muncul adalah, apakah konten pada setiap mata pelajaran telah mempertimbangkan aspek sikap? Mata pelajaran geografi pada Kurikulum 2013 memiliki muatan tentang keindonesiaan yang lebih signifikan sehingga diharapkan lebih dapat menumbuhkan patriotisme peserta didik. Mata pelajaran Geografi, baik pada Kurikulum 2004 maupun Kurikulum 2013, tampaknya tidak mengambil semua nilai karakter untuk dikembangkan, tetapi hanya beberapa saja yaitu mengembangkan patriotisme (cinta tanah air) dan peduli lingkungan. Sikap cinta tanah air dapat dikembangkan oleh semua mata pelajaran tetapi geografi memiliki tanggung jawab yang lebih besar karena memiliki misi memperkenalkan wilayah Indonesia, baik luas, bentuk, maupun potensinya.

Pada Seminar Geografi di Unversitas Muhammadiyah Purwokerto pada Sabtu 6 Juli 2013 sempat terungkap bahwa pemupukan rasa cinta tanah air dilatarbelakangi oleh naskah sumpah pemuda. Pada tahun 1928, jauh sebelum Indonesia merdeka, para pemuda Indonesia menyatakan sumpahnya yang sangat terkenal yaitu: Satu kami putra dan putri Indonesia, mengaku bertumpah 
darah yang satu, tanah air Indonesia. Kedua kami putra dan putri Indonesia, mengaku berbangsa yang satu, bangsa Indonesia. Ketiga kami putra dan putri Indonesia, menjunjung bahasa persatuan, bahasa Indonesia. Dalam perjalanannya, ketiganya tidak dipupuk secara bersama-sama. Usaha pemupukan rasa persatuan sebagai satu bangsa telah dilestarikan oleh mata pelajaran sejarah. Bahkan pada Kurikulum 1984, ada nama mata pelajaran Pendidikan Sejarah Perjuangan Bangsa (PSPB) sebagai mata pelajaran khusus yang membina rasa persatuan bangsa.

Untuk memupuk persatuan dalam penggunaan bahasa Indonesia, di semua jenjang pendidikan dari Sekolah Dasar sampai Sekolah Menengah Atas diberi mata pelajaran bahasa Indonesia bahkan di tingkat nasional didirikan Badan Pengembangan dan Pembinaan Bahasa untuk membina bahasa Indonesia. Adapun untuk memupuk nilainilai patriotisme (cinta tanah air) kurang diperhatikan. Dengan demikian, sekarang kita dapat memahami, mengapa rasa patriotisme mudah luntur, karena kita kurang fokus membina warga negara untuk mengenal wilayah negaranya sendiri. Oleh karena itu, geografi pada Kurikulum 2013 ditampilkan ke depan untuk memperkenalkan kembali wilayah dan potensi Indonesia agar generasi muda Indonesia mulai mencintai negaranya kembali.

Nilai patriotisme adalah nilai cinta tanah air yang ingin mempertahankan dan memelihara negaranya dari gangguan negara lain. Seperti kita memiliki rumah dan lahan pekarangan, kita akan mempertahankan keduanya dengan cara memantapkan hak kepemilikan dalam bentuk sertifikat tanah dan bangunan. Agar rumah menjadi nyaman, maka pemiliknya memelihara rumah dan pekarangan dengan sebaik mungkin. Lahan pekarangannya ditanami dengan tanaman dan bunga agar terasa lebih asri.

Dengan ilustrasi di atas, kita dapat memahami cara kita mencintai tanah air yaitu mencintai negara seperti mencintai tempat tinggalnya. Seseorang yang mencintai tanah airnya, maka ia akan mempertahankan kedaulatan wilayahnya, akan berusaha memakmurkan tanah airnya, dan memilihara kelestarian lingkungannya.

Undang-Undang Republik Indonesia Nomor 3 Tahun 2002 Tentang Pertahanan Negara menjelaskan bahwa wujud dari cinta tanah air adalah pembelaan terhadap negara dengan cara ikut serta dalam setiap kegiatan mempertahankan negara. Oleh karena itu, tidak seorang pun dari warga negara menghindar atau lepas tanggung jawab dari kewajibannya dalam membela negara.

Dalam prinsip ini terkandung pengertian bahwa upaya pertahanan negara seharusnya didasarkan pada kesadaran akan hak dan kewajiban sebagai warga negara serta memiliki keyakinan yang kokoh akan kekuatan sendiri (disarikan dari Bagian Umum Penjelasan dari Undang-Undang Republik Indonesia Nomor 3 Tahun 2002 Tentang Pertahanan).

Patriotisme terkadang dimaknai juga dengan hadirnya jiwa nasionalisme. Pemahaman ini tidak keliru, karena jiwa nasionalisme adalah rasa bertanggung jawab terhadap keutuhan bangsanya dari berbagai gangguan dari luar. Perbedaannya, untuk menumbuhkan jiwa nasionalisme dibutuhkan simbol-simbol dan kegiatan seremonial lainnya seperti menghormati bendera, lambang burung garuda, menyanyikan lagu kebangsaan Indonesia Raya, dan menggunakan bahasa Indonesia, atau mengharumkan nama bangsa dan negara Indonesia melalui prestasi akademik, olah raga, dan kesenian. Adapun patriorisme cenderung dimaknai dengan kegiatan nyata yang berdampak langsung maupun tidak langsung terhadap pembangunan bangsa dan negara seperti memilih produk dalam negeri daripada produk luar negeri, dalam pengembangan bakat dan minat kesenian dan budaya nasional, berusaha meningkatkan kualitas barang dan jasa produk dalam negeri agar laku dijual di negara lain, taat membayar pajak, mengembangkan ekonomi rakyat miskin, tidak korupsi, dan tidak melakukan perbuatan yang merugikan rakyat dan bangsa Indonesia.

Muatan nilai patriotisme tidak diajarkan di kelas tetapi dikembangkan melalui tiga tahap proses pengembangan yaitu melalui kegiatan pembelajaran agar peserta didik mengetahui nilai-nilai patriotisme (moral knowing), mengembangkan emosi (moral feeling) melalui penguatan emosi tentang moral seperti memberi pujian, teguran, dan bimbingan, dan terakhir melalui kegiatan moral action atau memberi contoh perbuatan yang bermoral (Kemendiknas, 2010).

Dalam kehidupan nyata di sekolah, guru (khususnya guru geografi) harus mampu menjadi teladan bagi peserta didik. Jika guru ingin menanamkan patriotisme dengan cara mencintai produk dalam negeri maka tentu saja di hadapan peserta didik tidak lagi makan dan minum dari jenis makanan yang serba produk luar negeri, dan secara konsisten memberi informasi tentang keunggulan 
kondisi alam Indonesia.

Di ruang kelas, guru geografi menyediakan berbagai media pembelajaran yang memiliki muatan informasi tentang Indonesia. Bahkan, memberi tugas kepada peserta didik adalah tugas geografi yang diberikan kepada peserta didik selalu yang bernafaskan Indonesia. Jika guru akan memberi tugas membuat peta, maka konten peta yang digambar adalah peta Indonesia dan atau pulau-pulau yang ada di wilayah Indonesia.

\section{Pembelajaran Geografi dalam Menumbuhkan Sikap Patriotisme}

Salah satu unsur perubahan yang terjadi pada Kurikulum 2013 adalah menggunakan model pembelajaran saintifik. Permendikbud Nomor 81A Tahun 2013 tentang Implementasi Kurikulum, Lampiran 4, tentang Pedoman Umum Pembelajaran menjelaskan bahwa model pembelajaran saintifik terdiri dari lima langkah pokok yaitu mengamati, menanya, mengumpulkan informasi, mengasosiasi, dan mengkomunikasikan. Kelima langkah tersebut harus dirancang oleh guru untuk setiap materi pokok dengan memerhatikan silabus. Bagaimana implementasi pembelajaran santifik dalam geografi? Tulisan ini akan menyampaikan informasi tentang pelaksanaan pembelajaran geografi dengan menggunakan model saintifik.

Langkah pertama untuk melaksanakan model saintifik dalam konteks Kurikulum 2013 adalah memahami konsep tentang hasil pembelajaran yang bersifat langsung (instructional effects) dan tidak langsung (nurturant effects). Ini perlu disampaikan karena guru harus memilih target utama dalam pembelajaran. Hasil pembelajaran yang bersifat langsung (instructional effects) meliputi ranah kognitif (KI-3) dan psikomotor (KI-4) sedangkan yang hasil pembelajaran yang tidak langsung adalah pengembangan sikap spiritual (KI-1) dan sosial (KI-2). Guru dituntut untuk mampu mencapai tujuan pembelajaran KI-3 dan KI-4 dan secara bersamaan mengembangkan sikap spiritual (KI-1) dan sikap sosial (KI-2).

Dalam mencapai tujuan pembelajaran tersebut, guru harus memiliki pandangan bahwa pembelajaran geografi tidak seperti menuangkan air ke dalam gelas kosong. Peserta didik hadir ke ruang kelas, sedikit atau banyak, telah memiliki pengetahuan awal walaupun mungkin masih sedikit. Tugas guru adalah menambah pengetahuan mereka agar lebih luas dan mendalam. Dengan demikian, guru tidak dianjurkan untuk terus-menerus berceramah, tetapi sebaiknya mengajak peserta didik untuk menemukan sendiri pengetahuan yang ingin diketahuinya sehingga menjadi miliknya yang tersimpan lama sebagai bekal kehidupannya di masa yang akan datang. Prinsip pembelajaran yang baik tersebut telah diakomodasi dalam kebijakan Kurikulum 2013 melalui pembelajaran saintifik.

Dalam banyak hal, pendekatan saintifik sebenarnya memiliki ciri yang bersifat kontekstual dan PAKEM (Pembelajaran Aktif Kreatif Efektif dan Menyenangkan). Artinya tidak jauh berbeda dengan gagasan kurikulum sebelumnya. Sebagaimana pendapat Kokom Komalasari (2011: 52), yang mengutip gagasan dari Bern and Erickson (2001), bahwa pembelajaran kontekstual memiliki melingkupi (1) pembelajaran berbasis masalah (problem-based learning); (2) cooperative learning (pembelajaran kooperatif); (3) pembelajaran berbasis proyek (project-based learning); dan (4) pembelajaran pelayanan (service learning).

Perhatikan Peraturan Menteri Pendidikan dan Kebudayaan Nomor 65 tahun 2013 tentang Standar Proses Pendidikan Dasar dan Menengah, dalam pembelajaran saintifik disarankan untuk melakukan pembelajaran yang menghasilkan karya berbasis pemecahan masalah (problembased learning) dan berbasis proyek (project based learning). Semua jenis pembelajaran yang disebutkan di atas, berorientasi kepada kegiatan peserta didik.

Bagaimana untuk mencapai mengembangkan patriotisme dalam pembelajaran geografi? Secara umum, strategi yang paling ampuh untuk mengembangkan karakter (termasuk patriotisme) adalah membangun komunikasi dan bekerjasama antara guru dengan peserta didik.

Elfindri, dkk (2012: 179) menyebut empat pilar dalam pembelajaran karakter yaitu (1) membangun komunikasi yang mendidik, (2) membangun keterampilan bekerjasama dalam teamwork; (3) membangun kepemimpinan; dan (4) membangun hubungan dan koneksitas.

Komunikasi yang baik antara guru dengan peserta didik adalah awal untuk saling memahami dan memudahkan bagi guru dalam memberi persuasi dan meningkatkan penerimaan peserta didik terhadap setiap nasihat dan arahan guru. Komunikasi yang buruk seperti tidak pernah bertegur sapa dan tidak harmonis hanya akan menutup peluang tumbuhnya karakter yang baik. Keterampilan membangun kerjasama dalam teamwork membuka peluang bagi peserta didik untuk mengekspresikan sikapnya. 
Dalam membangun sikap dan karakter terkadang tidak selamanya harus dikatakan, untuk mengungkapkan rasa terima kasih kepada seseorang, banyak orang yang mengekpresikannya dengan cara menghormati, rela berkorban untuk melayaninya sebagai bentuk balas budi. Membangun jiwa kepemimpinan adalah jalan masuk membangun karakter, karena dengan itu target karakter yang dibangun dapat terlihat jelas.

Sikap jujur, bertanggung jawab, disipilin, dan peduli sosial akan mudah dibangun dalam kegiatan kepemimpinan. Adapun membangun hubungan atau koneksi adalah membangun integritas agar dapat dipercaya oleh orang lain dan diterima dalam komunitasnya. Keempat aspek tersebut dapat dilakukan dalam setiap langkah pembelajaran saintifik. Pendekatan saintifik yang dilaksanakan secara benar akan membentuk karakter peserta didik. Berikut ini adalah daftar penggunaan metode pembelajaran yang memiliki nurturant effect yang berbeda.

Dalam konteks pembelajaran langsung (instructional effect), ada empat strategi pembelajaran geografi agar dapat menumbuhkan patriotisme peserta didik yaitu: (1) menyampaikan nasihat secara langsung tentang karakter patriotisme kepada peserta didik pada setiap kesempatan di tengah pembelajaran. Pada saat guru menjelaskan tentang kesuburan tanah air, pada saat ini guru dapat langsung memberi nasihat kepada peserta didik untuk bersyukur kepada Tuhan Yang Maha Esa dengan cara

Tabel 2

Pengaruh Metode Pembelajaran terhadap Dampak Ikutan (Nurturant Effect) Pengembangan Sikap Patriotisme

\begin{tabular}{|c|c|c|c|}
\hline No & $\begin{array}{c}\text { Metode } \\
\text { pembelajaran }\end{array}$ & $\begin{array}{l}\text { Dampak ikutan (nurturant effect) } \\
\text { kepada pengembangan sikap }\end{array}$ & $\begin{array}{c}\text { Dampak ikutan } \\
\text { (nurturant effect) kepada } \\
\text { pengembangan patriotisme }\end{array}$ \\
\hline 1 & Ceramah & $\begin{array}{l}\text { Meningkatkan rasa menghargai siswa } \\
\text { terhadap seseorang yang sedang berbicara } \\
\text { di depan dan menumbuhkan rasa ingin tahu }\end{array}$ & $\begin{array}{l}\text { Meningkatkan wawasan yang } \\
\text { berdampak pada tumbuhnya } \\
\text { rasa bangga menjadi warga } \\
\text { negara Indonesia }\end{array}$ \\
\hline 2 & Diskusi & $\begin{array}{l}\text { Mengembangkan sikap menghargai } \\
\text { pendapat orang lain, merangsang kreativitas } \\
\text { siswa dalam mengajukan ide gagasan dan } \\
\text { prakarsa, dan meningkatkan keberanian } \\
\text { bertanya dan mengajukan pendapat. }\end{array}$ & $\begin{array}{l}\text { Meningkatkan kepedulian } \\
\text { terhadap keutuhan tanah air } \\
\text { serta sensitif terhadap gagasan } \\
\text { yang tidak mencintai tanah air }\end{array}$ \\
\hline 3 & Tanya Jawab & $\begin{array}{l}\text { Mengembangkan berpikir logis dan } \\
\text { kritis, menumbuhkan keberanian, dan } \\
\text { menumbuhkan rasa tanggung jawab. }\end{array}$ & $\begin{array}{l}\text { Memantapkan keyakinannya } \\
\text { untuk tetap mencintai tanah } \\
\text { air (patriotisme) dan bangga } \\
\text { terhadap keyakinannya karena } \\
\text { dapat mengatakan gagasan } \\
\text { dan sikapnya kepada orang } \\
\text { lain. }\end{array}$ \\
\hline 4 & $\begin{array}{l}\mathrm{R} \text { e } \mathrm{s} \text { i t a } \mathrm{s} \text { i } \\
\text { (penugasan) }\end{array}$ & $\begin{array}{l}\text { Memberi kesempatan untuk memupuk } \\
\text { perkembangan dan keberanian mengambil } \\
\text { inisiatif, bertanggung jawab dan berdiri } \\
\text { sendiri, melatih peserta didik ke arah belajar } \\
\text { mandiri. Peserta didik dapat membagi waktu } \\
\text { secara teratur, dan melatih peserta didik } \\
\text { untuk menemukan sendiri cara-cara yang } \\
\text { tepat untuk menyelesaikan tugas. }\end{array}$ & $\begin{array}{l}\text { Dapat menumbuhkan kecintaan } \\
\text { yang semakin kuat terhadap } \\
\text { tanah air karena lebih banyak } \\
\text { mendapat informasi setelah } \\
\text { melaksanakan tugas-tugas } \\
\text { belajarnya }\end{array}$ \\
\hline 5 & Inquiry Learning & $\begin{array}{l}\text { Meningkatkan sensitivitas terhadap } \\
\text { permasalahan yang sedang dihadapi, } \\
\text { melatih berpikir logis, melatih berpikir } \\
\text { analisis ilmiah yang baik dan sistematis. } \\
\text { Meningkatkan sikap kritis dan bertanggung } \\
\text { jawab pada siswa, dan meningkatkan sikap } \\
\text { percaya diri pada siswa }\end{array}$ & $\begin{array}{l}\text { Dapat meningkatkan kemam- } \\
\text { puannya untuk mencari } \\
\text { bentuk-bentuk kegiatan yang } \\
\text { menunjukkan rasa cinta } \\
\text { tanah airnya, baik yang dapat } \\
\text { dilakukan oleh dirinya maupun } \\
\text { oleh orang lain. }\end{array}$ \\
\hline 6 & Role Playing & $\begin{array}{l}\text { Meningkatkan sikap kepemimpinan, } \\
\text { mmenerapkan rasa percaya pada teman, } \\
\text { meningkatkan rasa percaya diri, dan melatih } \\
\text { kejujuran. }\end{array}$ & $\begin{array}{l}\text { Dapat mengekpresikan secara } \\
\text { total dalam bentuk gagasan } \\
\text { dan sikapnya dalam bentuk } \\
\text { bermain peran. }\end{array}$ \\
\hline
\end{tabular}




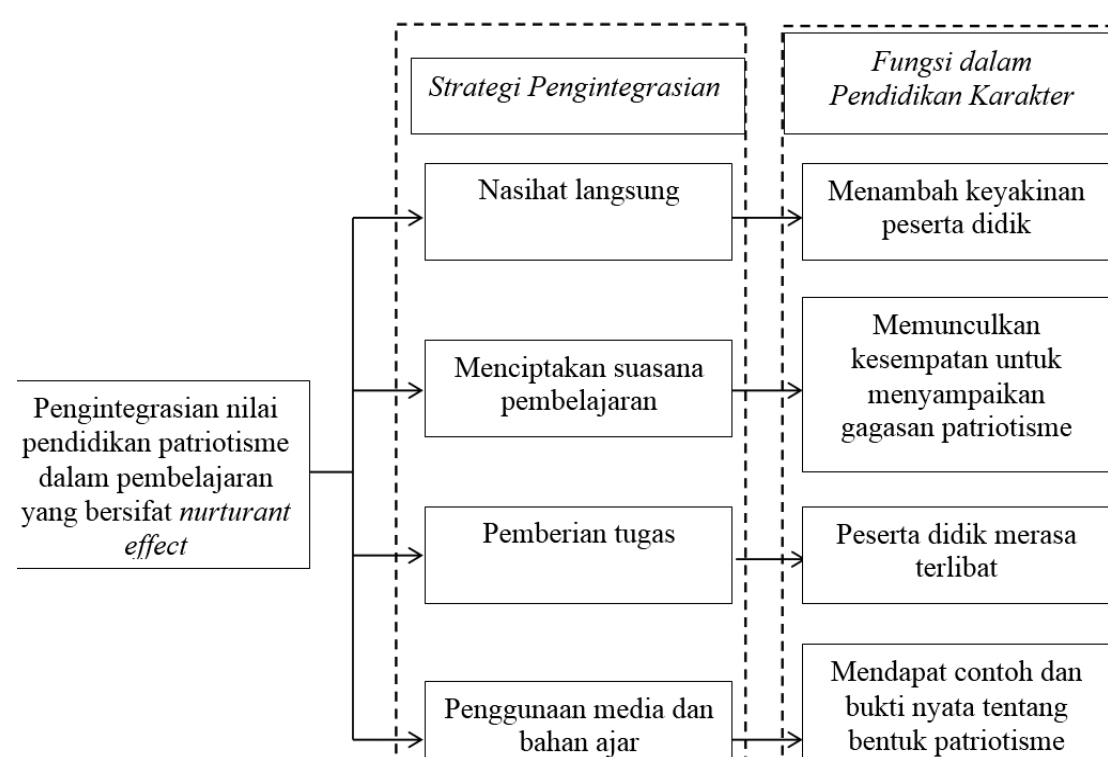

Gambar 1

Skema Pengintegrasian Nilai Pendidikan Karakter Cinta Tanah Air Dalam Pembelajaran

memelihara kelestariannya dan mengolahnya dengan sebaik-baiknya; (2) menciptakan suasana pembelajaran yang memungkinkan munculnya kesempatan bagi guru untuk menegur atau memberi penguatan (memuji dan menghargai) peserta didik. Sebagai contoh, jika guru menggunakan metode diskusi di ruang kelas pasti akan muncul pendapat dan atau perilaku peserta didik yang sesuai/tidak sesuai dengan prinsip-prinsip cinta tanah air. Pada saat yang tepat, guru dapat memberi komentar, memberi pujian (penguatan) dan meluruskan konsep jika ada pendapat peserta didik yang kurang tepat tentang cinta tanah air; (3) memberi tugas kepada peserta didik yang memungkinkan mereka mengenal wilayah negara dan menumbuhkan rasa cinta tanah air. Contoh sederhananya, peserta didik diminta untuk membuat kliping tentang keanekaragaman budaya dan keunikan jenis makanan khas dari setiap provinsi di Indonesia. Tugas pembuatan kliping harus diberi tanggapan atau komentar dari peserta didik tentang cara melestarian budaya bangsa tersebut; dan (4) penggunaan media dan bahan ajar yang diperkaya dengan nilai-nilai pendidikan karakter. Misalnya pemilihan foto dan gambar yang menumbuhkan motivasi untuk mencintai tanah air, mengangkat contoh-contoh kasus yang berbasis pada konteks keindonesiaan, bahkan dalam soalsoal latihan dapat diarahkan dengan cara mengajukan pertanyaan yang membangitkan rasa cinta tanah air. Berikut adalah skema strategi pengintegrasian nilai karakter dalam pembelajaran geografi dan fungsinya dari setiap strategi pembelajaran.

Dengan memerhatikan kesamaan antara pembelajaran saintifik dengan pembelajaran inkuiri, Penelitian Tindakan Kelas yang dilakukan oleh Zainuddin, dkk (2014; 11 - 17) memperkuat analisis di atas. Menurut Zainuddin, dkk, penerapan model inkuiri sangat berkontribusi terhadap pembentukan karakter peduli lingkungan dan memengaruhi kemampuan peserta didik dalam setiap tahap pembelajaran inkuiri.

Artkel ini berkesesuaian dengan hasil temuan peneliti bahwa dengan pembelajaran saintifik akan menghasilkan hasil belajar yang lebih optimal. Tidak hanya tercapai tujuan pada aspek kompetensi pengetahuan dan keterampian tetapi juga sikap spiritual dan sikap sosial. Jaminan model pembelajaran saintifik yang paling kuat adalah bahwa setiap tahap saintifik banyak memunculkan kesempatan (bagi guru) untuk menyampaikan dan membentuk karakter cinta tanah air dalam setiap pelaksanaan tugas yang dilaksanakan oleh peserta didik.

\section{Simpulan dan Saran}

Ada empat kesimpulan dari hasil penelitian ini yaitu: (1) Karakteristik mata pelajaran Geografi adalah mata pelajaran yang mempelajari hubungan kausal berbagai gejala dan peristiwa yang terjadi di muka bumi. Berdasarkan dokumen kurikulum dari Puskurbuk, geografi memiliki tujuan 
yang salah satunya untuk membina perilaku peserta didik agar cinta tanah air, bangga sebagai bangsa Indonesia, dan bertanggung jawab terhadap keutuhan Negara Kesatuan Republik Indonesia.

Dengan fakta ini dapat disimpulkan bahwa mata pelajaran geografi sengaja dikembangkan untuk menumbuhkan nilai-nilai patriotisme; (2) Jika dilihat dari materinya, mata pelajaran geografi pada Kurikulum 2013 menonjolkan materi yang bersifat keindonesiaan dibandingkan dengan kurikulum sebelumnya. Sebaran materi yang membahas materi tentang keindonesiaan ada pada kelas XI dan kelas XII. Fakta ini menunjukkan bahwa ada unsur kesengajaan kurikulum geografi diarahkan untuk membina nilai patriotisme; (3) Muatan nilai patriotisme pada mata pelajaran geografi pada Kurikulum 2013 juga terungkap pada seminar nasional di Universitas Muhammadiyah Purwokerto yaitu memiliki latar belakang untuk meneruskan semangat sumpah pemuda yaitu ingin memperkenalkan tanah air sebagai tumpah darah yang satu yaitu, tanah air Indonesia. Muatan nilai patriotisme dikembangkan melalui moral knowing, moral feeling, dan moral action; dan (4) untuk mengembangkan nilai patriotisme, pembelajaran Geografi dilakukan dengan pembelajaran yang bersifat langsung (instructional effects) dan tidak langsung (nurturant effects).

Dalam pembelajaran langsung, nilai patriotisme disampaikan melalui nasihat, menciptakan suasana pembelajaran yang memungkinkan munculnya kesempatan bagi guru untuk menegur atau memberi penguatan (memuji dan menghargai) peserta didik, memberi tugas kepada peserta didik yang memungkinkan mereka mengenal wilayah negara dan menumbuhkan rasa cinta tanah air, dan menggunakan media dan bahan ajar yang diperkaya dengan nilai-nilai pendidikan karakter. Adapun secara nurturant effect, nilai patriotisme dikembangkan melalui intensitas komunikasi dan bekerjasama antara guru dan peserta didik melalui metode-metode belajar yang efektif seperti diskusi,tanya jawab, bermain peran, inkuiri, dan pendekatan pembelajaran saintifik lainnya.

\section{Daftar Pustaka}

Daldjoeni. (2014). Pengantar Geografi. Yogyakarta. Penerbit Ombak.

Elfindri, dkk. (2012). Pendidikan Karakter
Kerangka, Metode dan Aplikasi untuk Pendidikan dan Profesional. Jakarta. Baduose Media.

Enok Maryani. (2015). Kecerdasan Ruang Dalam Pembelajaran Geografi. Makalah. Prosiding Seminar Nasional 1"Peringatan Hari Bumi untuk Meningkatkan Kecerdasan Ruang" ISSN LIPI 2443-1613. Program Studi Pendidikan Geografi Sekolah Pascasarjana Universitas Pendidikan Indonesia

Gunardo, R.B (2014). Geografi Politik. Yogyakarta. Penerbit Ombak

Jefriando. M. (2014). Di Awal Tahun Impor Garam Melonjak 75\%. Artikel. Tersedia on line detikfinance.com Selasa, 04/03/2014 12:05 WIB

Komalasari, K. (2011). Kontribusi Pembelajaran Kontekstual untuk Pengembangan Kompetensi Kewarganegaraan Peserta Didik SMP di Jabar. Artikel. Jurnal MIMBAR Vol. XXVII, No. 1 (Juni 2011): 47-55

Peraturan Menteri Pendidikan dan Kebudayaan Nomor 64 Tahun 2013 Tentang Standar Isi Pendidikan Dasar dan Menengah

Peraturan Menteri Pendidikan dan Kebudayaan Nomor 65 tahun 2013 tentang Standar Proses Pendidikan Dasar dan Menengah

Permendikbud Nomor 81A Tahun 2013 tentang Implementasi Kurikulum Lampiran 4 tentang Pedoman Umum Pembelajaran

Suharyono dan Moch. Amien. (2013). Pengantar Filsafat Geografi. Yogyakarta. Penerbit Ombak.

Undang-Undang Republik Indonesia Nomor 3 Tahun 2002 Tentang Pertahanan Negara

Yani, A. (2013). Persiapan Implementasi Kurikulum Geografi 2013. Makalah. Seminar Kurikulum pada Program Studi Pendidikan Geografi Universitas Muhammadiyah Purwokerto pada Sabtu 6 Juli 2013

Yani, A. (2014). Mindset Kurikulum 2013. Bandung. CV. Alfabeta.

Yani, A. dan Ningrum, E. (2014). Agenda Yogyakarta 2035: Mengukuhkan Mata Pelajaran Geografi Sebagai Pembentuk Karakter Bangsa. Makalah. Proceeding Seminar Nasional dan Kongres Ikatan Geograf Indonesia (IGI) ke XVII yang dilaksanakan pada tanggal 15 - 16 Nopember 2014 di UNY dan UGM, Yogyakarta.

Zainuddin, Mustofa, H, dan Hakam, DS. 2014. Membentuk karakter Peduli Lingkungan dengan Model Pembelajaran Inkuiri. Artikel. Jurnal MIMBAR Vol. 30. No. 1 (Juni 2014), hal. 11 - 17.

Kementerian Pendidikan Nasional. Direktorat Jenderal Manajemen Pendidikan Dasar dan Menengah. Direktorat Pembinaan Sekolah Menengah Pertama. 2010. Pembinaan Pendidikan Karakter di Sekolah Menengah Pertama. Jakarta 